$\begin{array}{ll}\text { Abstracta Iranica } & \begin{array}{l}\text { Abstracta Iranica } \\ \text { Revue bibliographique pour le domaine irano-aryen }\end{array} \\ & \text { Volume } \mathbf{3 7 - 3 8 - 3 9} \text { | } 2018 \\ & \text { Comptes rendus des publications de 2014-2016 }\end{array}$

\title{
Nadav Na'aman. "Abraham's Victory over the Kings of the Four Quadrants in Light of Darius I's Bisitun Inscription"
}

\section{Astrid Nunn}

\author{
(2) OpenEdition \\ Journals \\ Édition électronique \\ URL : http://journals.openedition.org/abstractairanica/45366 \\ DOI : 10.4000/abstractairanica.45366 \\ ISBN : 1961-960X \\ ISSN : 1961-960X \\ Éditeur : \\ CNRS (UMR 7528 Mondes iraniens et indiens), Éditions de l'IFRI
}

\section{Référence électronique}

Astrid Nunn, « Nadav Na'aman. "Abraham's Victory over the Kings of the Four Quadrants in Light of Darius I's Bisitun Inscription" », Abstracta Iranica [En ligne], Volume 37-38-39 | 2018, document 37, mis en ligne le 30 décembre 2018, consulté le 28 septembre 2020. URL : http://journals.openedition.org/ abstractairanica/45366 ; DOI : https://doi.org/10.4000/abstractairanica.45366

Ce document a été généré automatiquement le 28 septembre 2020.

Tous droits réservés 


\title{
Nadav Na'aman. "Abraham's Victory over the Kings of the Four Quadrants in Light of Darius I's Bisitun Inscription"
}

\author{
Astrid Nunn
}

\section{RÉFÉRENCE}

Nadav Na'aman. "Abraham's Victory over the Kings of the Four Quadrants in Light of Darius I's Bisitun Inscription", Tel Aviv (Journal of the Institute of Archaeology of Tel Aviv University) 42/1, 2015, p. 72-88.

1 L'A. étudie un passage de la Genèse (Genèse 14 « La campagne des quatre grands rois ») dans lequel Abraham vainc les quatre grands rois du Proche Orient. Selon lui, la source de ce récit pourrait être le relief de Darius à Bisutun, qui commémore sa victoire sur ses ennemis. Non que l'auteur du texte de la Genèse eût vu ce relief, mais il en connaissait vraisemblablement la description du texte et de l'iconographie victorieuse. Pour étayer sa thèse l'A s'attache tout particulièrement au style " chronistique et narratif », au flux du texte, aux noms et aux dates, au type de victoire du patriarche biblique et à l'instauration de la paix qui s'en suit. La date de Darius I s'accorderait à tous ces éléments, ce qui en conséquence impliquerait un terminus ante quem pour sa rédaction. 


\section{AUTEURS}

\section{ASTRID NUNN}

Université de Munich 